\title{
The Effects of Planting Distances and Different Stages of Maturity on the Quality of Three Cultivars of Tomatoes (Lycopersicon esculentum Mill)
}

\author{
Atefeh TABASI ${ }^{1 *}$, Hossein NEMATI ${ }^{1}$, Mohammad AKBARI ${ }^{2}$ \\ ${ }^{1}$ Ferdowsi University of Mashhad, Faculty of Agriculture, Department of Horticulture, \\ Mashhad,Iran; a.tabasi86@gmail.com (*correspondingauthor) \\ ${ }^{2}$ Rasht University of Guilan, College of Agriculture, Department of Horticulture, Guilan, Iran
}

\begin{abstract}
In this investigation the effects of cultivar, row spacing and different stages of maturity on qualitative characteristics of tomato (ascorbic acid, total soluble solids (TSS), $\beta$-carotene and lycopene) have been evaluated. Experiment was performed by factorial analysis with 3 replicates in completely randomized design (CRD). First treatment was three cultivars of tomato, second treatment was four planting distances and third treatment was different stages of maturity. The results showed that all treatments had significant influence on the levels of ascorbic acid, soluble solids, $\beta$-carotene and lycopene. Generally, wider spacing and deep red fruits had the highest quality. Therefore, choosing appropriate cultivars, special planting distances and suitable stage of maturity can increase fruit quality of tomato.
\end{abstract}

Keywords: ascorbic acid, carotenoid, lycopene, soluble solids, spacing

\section{Introduction}

Lycopen, a participant in the carotenoid family along with a pigment which attributes to the red color of tomatoes, is a leading factor to its health promoting ability (Tonucci et al., 1995; Fanasca et al., 2007). Many studies have shown that tomatoes can help decrease the chance of getting lung cancer, because lycopene acts as antioxidant (Young et al., 1993). Qualitative factors of tomato (flavor, color, soluble solids and nutrition value) were affected by cultivar, weather, condition storage, fruit maturity and cultivation methods (Gould, 1983). Changes in tomato fruit ripening occur within the plastids after the disappearance of chlorophyll. The two major groups of pigments found in tomato fruit are chlorophyll and carotenoids. The most noticeable change during ripening is the remarkable increase in the carotenoid content of the fruit (Laval-Martin et al., 1975). During ripening the chlorophyll concentration decreases while carotenoids, especially lycopene, accumulate in the fruit (Laval-Martin et al., 1975). According to Brandt et al. (2003) higher lycopene content was observed in tomato harvested in glasshouse-grown than in field-grown at different harvesting times. As suggested by Luh and Daoud (1968) the amount of lycopene in different cultivars reveals a considerable difference. The light intensity is influential in the biosynthesis of carotenoids and development of fruit color (Shiraghinge et al., 2010). Ascorbic acid, total soluble solids (TSS) and contents are commonly considered as fruit quality determining properties in tomato. Soluble solids include mainly the sugars such as glucose, fructose and sucrose. In tomato fruit, or- ganic acids with sugars make a major contribution to the taste of the fruit. Most variation in flavor can be related to differences in the sugars and acids contents of the fruits. Bradly (1964) and Mauz (1966) showed that there is a fundamental difference in acidity between tomato cultivars. Although the cultivar has a dominant influence on the quality determinant properties, the environment in which it grows also has a significant impact on quality characters (Purseglove et al., 1986). As shown by Malewski and Markakis (1971) ascorbic acid content decreases with ripening thus conflicting results could have been due to differences in ripeness at time of analysis.

Spacing is one of the important factors, which influence the quality of tomato fruit. Many experiments have been conducted on the effect of spacing on growth and quality of tomato. Tanaka and Komochi (1982) studied the relationship between plant density and topping on the growth and quality of tomato in greenhouse. They reported with increasing plant density, leaf size, stem diameter, weight of leaves and stem per plant decreased and flowering as well as ripening was delayed up to 7 days and yield per unit area increased. Srinivas and Hegde (1984) demonstrated that increased spacing increased dry matter production and quality attributes of tomato. A positive correlation was reported between plant density and yield and negative correlation between plant density and quality of fruits, so that the highest fruit quality was recorded in lowest plant density (Manchanda and Bhopal Singh, 1988). Gaye et al. (1992) reported that quality attributes of tomato declined with increasing plant density (Davies and Hobson, 1981; Baxter et al., 2005). Srinivasa et al. (1988) observed that 
372

wider row spacing gave significantly more fruit quality than narrow spacing in tomato cultivars.

Optimum plant spacing may help in proper utilization of land and for obtaining good quality fruits. On the other hand, stem pruning also may influence on the production of yield. Therefore, the present study was undertaken to investigate the effect of optimum plant density and different stages of maturity for higher yield and better quality of tomato.

\section{Material and methods}

\section{Plant materials and treatments}

In this study three cultivars of tomato ('Super A', '1449', and 'Nemark 49') grown in greenhouses of (Ferdowsi University of Mashhad in Iran). Each tomato cultivar was planting in four distances $(25 \mathrm{~cm}, 33 \mathrm{~cm}, 41 \mathrm{~cm}$ and 49 $\mathrm{cm})$. These planting distances are common in this area The purpose of these intervals, was Investigate the effect of light and environmental conditions on fruit quality. Fruit sample from four maturity stages according Huerres Perez (1987) were gathered randomly by hand in three repetitions. Stages of maturity were classified as follows:

Mature green: fruits are mature and entirely light to dark green.

Pink: pink or red color ranges between 10 to $30 \%$.

Red: red color is more than $60 \%$ but less than $90 \%$.

Deep-red: red color exceeds 90\% (Yamaguchi, 1983).

Traits measured were included soluble solid, ascorbic acid, $\beta$-carotene and lycopene at four different stages of fruit ripening.

\section{Soluble solids analysis}

Total soluble solid contents were determined by extracting and mixing one drop of juice from each fruit into a refractometer (ERMA, TOKYO).

\section{Ascorbic acid analysis}

Ascorbic acid was measured according to the method of AOAC (2005). In order to measure the ascorbic acid, $10 \mathrm{~cm}^{3}$ from tomato juice was mixed with $20 \mathrm{cc}$ distilled water and then $2 \mathrm{cc}$ from (1\%) one-percent soluble starch was added. Then ascorbic acid was determined by titration of $10 \mathrm{ml}$ filtrated juice which contained potassium iodide (KI). In fact, it was based on mg ascorbic acid per100 g FW. Ascorbic acid content was calculated using the following formula (AOAC, 2005).

\section{$\beta$ - Carotene analysis}

The $\beta$-carotene was analyzed by a modified AOAC method (AOAC, 1970) and was extracted with an acetone-hexane mixture. The MgO-Hyflo Supercel chromatographic column was washed with $0.5 \%$ acetone in hexane so that isomerization of carotenoids would be minimized (Wiseman et al., 1952). $\beta$-carotene was eluted with $5 \%$ acetone in hexane. The concentration of $\beta$-carotene was based on the absorbance at $451 \mathrm{~nm}$ with an extinction coefficient of 2505 (Goodwin, 1955).

\section{Lycopene analysis}

The tomato samples (approximately $500 \mathrm{mg}$ ) were ground in a mortar in liquid nitrogen, followed by grinding in $4 \mathrm{ml}$ of acetone with $50 \mathrm{mg} \mathrm{CaCO}$. After centrifugation, pellets were re-extracted with $4 \mathrm{ml}$ of acetone, $2 \mathrm{ml}$ of hexane and 5 of $\mathrm{ml}$ acetone: hexane (4:1), successively. The supernatants were combined, measured and filtered through $0.2 \mu \mathrm{m}$ nylon syringe filters into HPLC vials. All processes were performed as much as possible under subdued or safe light and a nitrogen atmosphere. For HPLC analysis a Spectra Physics SP8800 pump system was used equipped with a Spectra Physics Spectra 100 UV-Vis detector (Spectra Physics, Mountain View, CA, USA). For system processing and data acquisition a computer system with WINner on Windows software was used (Thermo Separation Products, Wirral, UK). Sample injections were carried out by means of a Waters 717 (Milford, MA, USA) autosampler equipped with a cooler. Separation of the pigments was carried out according to Gilmore and Yamamoto (1991) using a non-endcapped Allsphere ODS-1 HPLC column $(4.6 \mathrm{~mm} \times 250 \mathrm{~mm}, 5 \mu \mathrm{m}$ particle size $)$ preceded to a ODS-1guard column (Alltech Associates). Stainless steel column frit/insert material was replaced by a Peek Alloyed with Teflon (PAT) column frit/insert. The column temperature was $30^{\circ} \mathrm{C}$. The mobile phase consisted of acetonitrile, methanol and tris buffer $0.1 \mathrm{M}(\mathrm{pH}$ 8.0). The mobile phase contained $0.1 \%(\mathrm{w} / \mathrm{v}$ ) butylated hy-

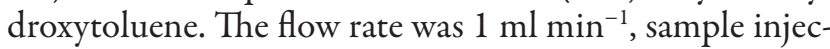
tion volume was $20 \mu \mathrm{l}$ and spectrophotometric detection was performed at $445 \mathrm{~nm}$. The concentrations of pigment standard stock solutions were determined spectrophotometrically using published absorbance coefficients (Konings and Roomans, 1997).

\section{Statistical analysis}

Effect of treatments were verified based on ANOVA using Excel program and the means were compared using LSD test at 5\% level.

\section{Results and discussion}

\section{Ascorbic acid}

The experiment results demonstrated that there was a vital difference between three cultivars, planting distances and different stages of fruit ripening in ascorbic acid content. So the highest content of ascorbic acid was related to deep red fruits in $49 \mathrm{~cm}$ of planting distance (Tab. 2). As shown by Sing and Dillon (1986) the ascorbic acid and other acidity content of tomato juice was increased with maturity stages and reached the peak and thereafter started to decrease Singh and Dillon (1986). Also our results are similar to Mauz (1966) who reported that increasing light in to the plant leads to raised ascorbic acid. It can 
be concluded that in $49 \mathrm{~cm}$ of row spacing, more light to the crown of the plant was penetrated, which results in increased fruit ascorbic acid. Mahendran and Bandara (2000) reported that moisture stress reduced the ascorbic acid content of tomato fruits when the stress was imposed during the fruit ripening stage. It can be concluded that close spacing retains soil moisture. Also they stated a reduction in the D-glucose synthesis would have occurred during the period of stress, which in turn may have reduced the synthesis of ascorbic acid. Moisture stress may have reduced the substrate concentration for ascorbic acid synthesis. Reduction in the substrate may possibly be due to reduced photosynthetic rate (Mahendran and Bandara 2000).

\section{Total soluble solids (TSS)}

The study results revealed that there was a significant difference between three cultivars, row spacing and different stages of fruit ripening in soluble solids. The most soluble solids were obtained from red fruits of 'Super A' cultivar in the $49 \mathrm{~cm}$ of plant-spacing. Fernando and Alisdair (2006) suggested more space of planting distances increased photosynthesis which results in increased soluble solids. It should be noted that there are a lot of light penetrated in wider spacing in comparison with close spacing. Purseglove et al. (1986) reported that fruit ripening had a major impact on quality attribute and raised the dry matter of fruit and soluble solids. These results are in close agreements with our findings (Tab. 1).

\section{$\beta$-Carotene}

The results of this experiment showed that cultivar, row spacing and different stages of fruit ripening had central effects on carotenoied level, so that the highest $\beta$-carotene content belonged to 'Nemark 49' cultivar in 49 cm of planting distance of pink fruits (Tab. 3).

Young et al. (1993) mentioned that there is a prominent difference between cultivars. They also expressed that presence amount of carotenoid in some cultivars and their absence in the other varieties is due to differences in their genes controlling biosynthesis. In addition, they reported that light density is a major factor to improve carotenoid Chlorophyll content. Bradly (1964) stated that fruits receiving more light have higher levels of carotenoid. So, it can be concluded that increasing row spacing, revealed a better penetration of light to the crown of the plant that leads to $\beta$ - carotene content increasing.

\section{Lycopene}

The results demonstrated that cultivar, row spacing and different stages of ripening fruit had an essential difference on lycopene level. The results of our investigation established that the content of lycopene in all the investigated tomatoes during fruit ripening significantly increased. The lowest concentration of lycopene $\left(32 \mathrm{mg} 100 \mathrm{~g}^{-1}\right)$ was recorded in the green fruits of the cultivar '1449', in $25 \mathrm{~cm}$ of row spacing and the highest concentration of lycopene (434 mg $100 \mathrm{~g}^{-1}$ ) was measured in completely ripened tomatoes of the cultivar 'Nemark 49' in $41 \mathrm{~cm}$ of row spacing (Tab. 4). Muhammad and Singh (2007) reported that

Tab. 1. Comparison of interaction between variety, row spacing and different stages of maturity for TSS

\begin{tabular}{|c|c|c|c|c|c|c|c|c|c|c|c|c|c|c|c|c|c|}
\hline \multirow{2}{*}{\multicolumn{2}{|c|}{$\begin{array}{l}\text { Different stages } \\
\text { Planting distances }\end{array}$}} & \multicolumn{4}{|c|}{ green } & \multicolumn{4}{|c|}{ pink } & \multicolumn{4}{|c|}{ red } & \multicolumn{4}{|c|}{ deep red } \\
\hline & & 25 & 33 & 41 & 49 & 25 & 33 & 41 & 49 & 25 & 33 & 41 & 49 & 25 & 33 & 41 & 49 \\
\hline \multirow{3}{*}{ Cultivar } & 'Super A' & $2.2^{1}$ & $2.3^{\mathrm{k}}$ & $2.7^{i}$ & $2.8^{\mathrm{i}}$ & $3.0^{\mathrm{h}}$ & $3.1^{\mathrm{g}}$ & $3.1^{g}$ & $3.2^{\mathrm{f}}$ & $3.45^{\mathrm{e}}$ & $3.46^{\mathrm{e}}$ & $3.68^{\mathrm{d}}$ & $3.7^{\mathrm{d}}$ & $4^{\mathrm{b}}$ & $3.9^{c}$ & $4.38^{\mathrm{a}}$ & 4. $9^{2}$ \\
\hline & '1449' & $2.2^{k}$ & $2.65^{j}$ & $2.65^{j}$ & $2.7^{i}$ & $3.1^{\mathrm{i}}$ & $3.35^{\mathrm{h}}$ & $3.5^{\mathrm{g}}$ & $3.46^{g}$ & $3.68^{f}$ & $3.7^{\mathrm{f}}$ & $3.98^{e}$ & $4^{e}$ & $4.3^{\mathrm{d}}$ & $4.5^{\mathrm{c}}$ & $4.7^{b}$ & $4.4^{a}$ \\
\hline & 'Nemark 49' & $2.6^{\mathrm{i}}$ & $2.3^{\mathrm{k}}$ & $2.4^{j}$ & $2.6^{\mathrm{i}}$ & $2.76^{\mathrm{h}}$ & $2.8^{\mathrm{h}}$ & $2.98^{g}$ & $3.0^{g}$ & $3.13^{\mathrm{f}}$ & $3.2^{\mathrm{f}}$ & $3.36^{\mathrm{e}}$ & $3.4^{\mathrm{e}}$ & $3.6^{\mathrm{d}}$ & $3.7^{\mathrm{c}}$ & $3.8^{\mathrm{b}}$ & $4.4^{\mathrm{a}}$ \\
\hline
\end{tabular}

Means with similar letters in each table are not significantly different by LSD multiple range test $(p<0.05)$

Tab. 2. Comparison of interaction between variety, row spacing and different stages of maturity for ascorbic acid

\begin{tabular}{|c|c|c|c|c|c|c|c|c|c|c|c|c|c|c|c|c|c|}
\hline \multirow{2}{*}{\multicolumn{2}{|c|}{$\begin{array}{l}\text { Different stages } \\
\text { Planting distances }\end{array}$}} & \multicolumn{4}{|c|}{ green } & \multicolumn{4}{|c|}{ pink } & \multicolumn{4}{|c|}{ red } & \multicolumn{4}{|c|}{ deep red } \\
\hline & & 25 & 33 & 41 & 49 & 25 & 33 & 41 & 49 & 25 & 33 & 41 & 49 & 25 & 33 & 41 & 49 \\
\hline \multirow{3}{*}{ Cultivar } & 'Super A' & $11.86^{\mathrm{i}}$ & $12.70^{\mathrm{h}}$ & $14.46^{\circ}$ & $14.20^{\mathrm{g}}$ & $17.03^{f}$ & $17.26^{\mathrm{f}}$ & $20.9^{\mathrm{ds}}$ & $20.3^{\text {de }}$ & $23.8^{\mathrm{b}}$ & $23.2^{a}$ & $27.46^{a}$ & $27.10^{\mathrm{a}}$ & $20.10^{\mathrm{e}}$ & $20.86^{d}$ & $22.33^{\mathrm{c}}$ & $22.40^{c}$ \\
\hline & '1449' & $11.73^{j}$ & $12.40^{i}$ & $14.66^{\mathrm{h}}$ & $14.06^{\mathrm{h}}$ & $16.30^{\mathrm{g}}$ & $17.63^{f}$ & $20.3^{\mathrm{de}}$ & $19.9^{d}$ & $23.1^{\mathrm{b}}$ & $23.5^{\mathrm{a}}$ & $27.36^{a}$ & $27.16^{a}$ & $20.30^{\text {de }}$ & $20.60^{d}$ & $22.03^{c}$ & $21.76^{c}$ \\
\hline & 'Nemark 49’ & $11.56^{\mathrm{i}}$ & $12.13^{\mathrm{i}}$ & $14.63^{\mathrm{h}}$ & $14.30^{\mathrm{h}}$ & $16.53^{\mathrm{g}}$ & $17.23^{f}$ & $20.6^{\mathrm{d}}$ & $21.0^{\mathrm{e}}$ & $23.9^{\mathrm{b}}$ & $23.5^{\mathrm{a}}$ & $26.96^{a}$ & $26.53^{a}$ & $19.96^{\mathrm{e}}$ & $20.43^{\text {de }}$ & $21.66^{\mathrm{c}}$ & $21.06^{\mathrm{cd}}$ \\
\hline
\end{tabular}

Means with similar letters in each column are not significantly different by LSD multiple range test $(p<0.05)$

Tab. 3. Comparison of interaction between variety, row spacing and different stages of maturity for B-carotene

\begin{tabular}{|c|c|c|c|c|c|c|c|c|c|c|c|c|c|c|c|c|c|}
\hline \multirow{2}{*}{\multicolumn{2}{|c|}{$\begin{array}{l}\text { Different stages } \\
\text { Planting distances }\end{array}$}} & \multicolumn{4}{|c|}{ green } & \multicolumn{4}{|c|}{ pink } & \multicolumn{4}{|c|}{ red } & \multicolumn{4}{|c|}{ deep red } \\
\hline & & 25 & 33 & 41 & 49 & 25 & 33 & 41 & 49 & 25 & 33 & 41 & 49 & 25 & 33 & 41 & 49 \\
\hline \multirow{3}{*}{ Cultivar } & 'Super A' & $51.0^{f}$ & $51.4^{\mathrm{f}}$ & $57.4^{\mathrm{e}}$ & $49.4^{\mathrm{f}}$ & $258^{d}$ & $263^{c}$ & $288^{a}$ & $271.4^{\mathrm{b}}$ & $24^{g}$ & $21.4^{\mathrm{h}}$ & $7.4^{i}$ & $11^{i}$ & $0.50^{\mathrm{k}}$ & $0.76^{k}$ & $0.50^{\mathrm{k}}$ & 0.16 \\
\hline & '1449' & $63.7^{\mathrm{g}}$ & $66.7^{f}$ & $69.4^{\mathrm{e}}$ & $64.4^{\mathrm{g}}$ & $228^{d}$ & $238.7^{\mathrm{c}}$ & $251.7^{\mathrm{b}}$ & $264.7^{\mathrm{a}}$ & $35.4^{g}$ & $27^{\mathrm{h}}$ & $19.4^{\mathrm{i}}$ & $17^{j}$ & $8.26^{\mathrm{k}}$ & $9.7^{\mathrm{k}}$ & $5.3^{1}$ & $7.4^{k}$ \\
\hline & 'Nemark 49' & $36.4^{\mathrm{f}}$ & $36^{\mathrm{f}}$ & $35.7^{\mathrm{f}}$ & $37.4^{\mathrm{f}}$ & $313^{d}$ & $324^{c}$ & $342.4^{\mathrm{b}}$ & $351^{a}$ & $58^{e}$ & $39^{\mathrm{e}}$ & $31.7^{\mathrm{h}}$ & $23.7^{\mathrm{i}}$ & 11.4 & $12.5^{j}$ & $7.6^{\mathrm{k}}$ & $6.8^{k}$ \\
\hline
\end{tabular}

Means with similar letters in each column are not significantly different by LSD multiple range test $(p<0.05)$ 
Tab. 4. Comparison of interaction between variety, row spacing and different stages of maturity for lycopene

\begin{tabular}{|c|c|c|c|c|c|c|c|c|c|c|c|c|c|c|c|c|c|}
\hline \multirow{2}{*}{\multicolumn{2}{|c|}{$\begin{array}{l}\text { Different stages } \\
\text { Planting distances }\end{array}$}} & \multicolumn{4}{|c|}{ green } & \multicolumn{4}{|c|}{ pink } & \multicolumn{4}{|c|}{ red } & \multicolumn{4}{|c|}{ develop red } \\
\hline & & 25 & 33 & 41 & 49 & 25 & 33 & 41 & 49 & 25 & 33 & 41 & 49 & 25 & 33 & 41 & 49 \\
\hline \multirow{3}{*}{ Cultivar } & 'Super A' & $50^{k}$ & $55^{j}$ & $60^{i}$ & $68^{\mathrm{h}}$ & $217^{\mathrm{g}}$ & $223^{f}$ & $226^{\mathrm{e}}$ & $235^{d}$ & $37^{\mathrm{c}}$ & $371.7^{\mathrm{c}}$ & $374.7^{\mathrm{b}}$ & $377^{\mathrm{b}}$ & $411.7^{\mathrm{a}}$ & $411^{2}$ & $411.4^{a}$ & $409.7^{\mathrm{a}}$ \\
\hline & '1449’ & $32^{\circ}$ & $37.4^{\mathrm{n}}$ & $42^{\mathrm{m}}$ & $51.4^{1}$ & $165^{\mathrm{k}}$ & $172^{g}$ & $183^{\mathrm{i}}$ & $196.7^{\mathrm{h}}$ & $301.7^{g}$ & $307.4^{f}$ & $311.4^{e}$ & $316.4^{d}$ & $361^{\mathrm{b}}$ & $368.7^{a}$ & $357.4^{c}$ & $370.4^{a}$ \\
\hline & 'Nemark 49' & $61.4^{\mathrm{m}}$ & $73.4^{1}$ & $83^{\mathrm{k}}$ & $98^{j}$ & $23^{i}$ & $246.4^{\mathrm{h}}$ & $260.4^{\mathrm{g}}$ & $277^{\mathrm{f}}$ & $381^{\mathrm{e}}$ & $389^{\mathrm{d}}$ & $386.4^{d}$ & $386.4^{c}$ & $420.4^{b}$ & $431.4^{a}$ & $434.4^{a}$ & $418^{\mathrm{b}}$ \\
\hline
\end{tabular}

Means with similar letters in each column are not significantly different by LSD multiple range test $(p<0.05)$

the amount of lycopene is influenced by the cultivar. Anderson (1969), Uddin et al. (1997) and Muhammad and Singh (2007) reported that plant spacing had a large affect on the PAR (photo synthetically active radiation) so the ratios of blue, far-red, red far and blue red as a result of decreased plant density were increased. This issue has an impact major on lycopen level. Also, Law and Eghrevba (2009) showed that tomato fruit exposed to sunlight during ripening contained more lycopene than those ripened in shade.

\section{Conclusions}

Several factors including: cultivar, row spacing and different stages of maturity can influence ascorbic acid, soluble solids, $\beta$-carotene and lycopene in tomato fruits. According to this study, sunlight is a crucial factor on fruit quality. In general, increasing row spacing causes more light enter to the plant, so it increases ascorbic acid, lycopen and carotenoids content. In high row spacing, more photosynthesis take place because there is more light penetration in to the canopy and thus increases the amount of total soluble solids.

\section{References}

Aoac (1970). “Official Methods of Analysis", Horwitz W (Ed.). Assoc of Official Anal Chemistry, Washington, DC, USA, $769 \mathrm{p}$.

Aoac (2005). Official method of analysis. $18^{\text {th }}$ ed. Association of official agricultural chemistry Washington, DC. USA.

Anderson MC (1969). A comparison of two theories of scattering of radiation in crops. Agric Meteorol 6:399-405.

Baxter CJ, Carrari F, Bauke A, Overy S, Hill SA, Quick PW, Fernie AR, Sweetlove LJ (2005). Fruit carbohydrate metabolism in an introgression line of tomato with increased fruit soluble solids. Plant Cell Physiol 46(3):425-437.

Bradly Db (1964). Tomato composition, Varital and location influence on acid composition of tomato fruit. Agric and Food Chem 12:231-234.

Brandt S, Pék Z, Barna E (2003). Lycopene content and colour of ripening tomatoes as affected by environmental conditions. J Sci Food and Agric 86:568-572.

Davis JR, Hobson GE (1981). The constituents of tomato fruit the influence of environment, nutrition, and genotype. Critical Rev Food Sci Nutrition 15(3):205-280.

Fanasca A, Martino A, Heuvelink E, stanghelini C (2007). Ef- fect of electrical conductivity fruit pruning and truss position on quality in green house tomato fruit. J Hortic Sci and Biotechnol 62:488-494.

Fernando C, Alisdair RF (2006). Metabolic regulation underlying tomato fruit development. J Experim Bot 57(9):18831897.

Gaye MM, Jolliffe PA, Maurer AR (1992). Row cover and population density effects on yield of bell pepper in South Coastal British Columbia. Canadian J Pl Sci 72:901-909.

Gilmore AM, Yamamoto HY (1991). Resolution of lutein and zeaxanthin using a non-endcapped, lightly carbon-loaded c-18 high-performance liquid- chromatographic column. J Chromatogr 543:137-145.

Goodwin TW (1955). In: Paech K, Tracey MV (Eds.). Modern methods of plant analysis, Springer, Heidelberg 3:272.

Gould AA (1983). Tomato Production and quality evaluation. AVI, New York, U.S.A, West port, Connecticut: AVI publishing $478 \mathrm{p}$.

Huerres Perez C, Caraballo LN, Margolles J (1987). Effect of planting distance and number of plants per cluster in 3 cultivars of processing tomatoes (Lycopersicon esculentum Mill). Centro Agricola 14:(3):21-30.

Konings E, Roomans H (1997). Evaluation and validation of an LC method for the analysis of carotenoids in vegetables and fruit. J Food Chem 59:599-603.

Laval-Martin D, Quennemet J, Moneger R (1975). Pigment evolution in Lycopersicon esculentum fruits during growth and development. Photochemistry 14:2357-2362.

Law-Ogbomo KE, Egharevba RKA (20090. Effects of planting density and NPK fertilizer application on yield and yield components of tomato (Lycospersicon esculentum Mill) in forest location. J Agric Sci 5(2):152-158.

McCoBum JP (1954). Effects of light on the formation of carotenoids in tomato fruits. Food Res 19:182.

Mahendran S, Bandara DC (2000). Effects of soil moisture stress at different growth stages on vitamin $\mathrm{C}$, capsaicin, and $\beta$-carotene contents of chilli (Capsicum annum L.) fruits and their impact on yield. Trop Agric Res 12:95-106.

Malewski W, Markakfs P (1971). Ascorbic acid content of develop in tomato fruit. J Food Sci 36(3):537.

Manchanda AK, Bhopal S (1988). Effect of plant density and nitrogen on growth and fruit yield of bell pepper (Capsicum annuum L.). Indian J Agron 33(4):445-447.

Mauz F (1966). Flavor of fresh market tomato (Lycopersicon esculentum Miil) as influence by harvest maturity and storage temperature. Ph. D thesis. 
Muhammad A, Singh A (2007). Intra-row spacing and pruning effects on fresh tomato yield in Sudan Savanna of Nigeria. J Plant Sci 2:153-161.

Purseglove JW, Brown EG, Green CL, Robbins SRJ (1986). Spices. Tropical Agriculture Series, Vol. 1, Longman Group Ltd., London.

Shiraghinge FH, Mello PCT, Jacomino AP, Melo AMT, Purquerio LFV, Roquejani MS (2010). Yield and qualitative characterization of fresh market tomato hybrids of Italian and Santa Cruz type. J Hortic Bras 80:292-298.

Singh GH, Dillon TS (1986). Some aspects of seed extraction in tomato seed. Research 13(2):67-72.

Srinivas K, Hegde DM (1984). Growth analysis of capsicum (Capsicum annuum L.) cultivars in relation to plant spacing. Singapore J Primary Industries 12(2):152-158.

Srinivasa S, Ramegowda A, Bommegowda A (1988). Response of tomato varieties to different nitrogen levels and spacing geometry. Curr Res 17(1):7-8.
Tanaka M, Komochi S (1982). Research bulletin of Hokkaido National Agricultural Experimental Station 35:83-99.

Tonucci LH, Holden JM, Beecher GR, Khachik F, Davis CS, Mulokozi G (1995). Carotenoid content of thermally processed tomato-based food-products. J Agric Food Chem 43:579-586.

Uddin M, Hossain R, Mian MA, Uddin MAK, Reza MZ, Mahtabuddin AKM (1997). Effect of stem pruning and spacing on the growth and yield of Tomato. Bangladesh Hort 25(1\&2):41-46.

Young TE, Juvik JA, Sullivan JG (1993). Accumulation of the components of total solids in ripening fruits of tomato. J Hort Sci 118(2):286-292.

Wiseman HG, Stone SS, Savage HL, Moone LA (1952). Aotion of celites on carotene and lutein. Anal Chem. 